\title{
LINGUAGEM E LEITORES: REFLEXÕES SOBRE ENSINO
}

\author{
Ana Crélia Penha DIAS \\ (Universidade Federal do Rio de Janeiro) \\ anacrelia@gmail.com.br
}

WILSON, Victoria. MORAIS, Jaqueline. Leitura, escrita e ensino: discutindo a formação de leitores. São Paulo: Summus, 2015.

As discussões acerca do ensino de Língua Portuguesa remontam há algum tempo e já alcançam, mesmo que não ainda no patamar desejado, muitos espaços que a consolidam e desdobram: estão nos documentos oficiais; aparecem nos livros didáticos, mesmo que ainda não substancialmente; frequentam os currículos de graduação; já conseguiram chegar ao olimpo da pós-graduação.

Em se tratando de leitura e, especificamente, de literatura, são ainda raros os espaços que se dedicam a dar continuidade aos caminhos há muito iniciados por Ligia Chiappini, Regina Zilberman e Marisa Lajolo, para citar algumas referências. As relações da literatura com a leitura e o ensino ainda se calam aos documentos oficiais, repetem formas obsoletas nos livros didáticos, raramente frequentam os estudos da graduação em Letras; e sequer chegam à pós-graduação.

O volume Leitura, escrita e ensino: discutindo a formação de leitores, nesse sentido, junta-se a um certo levante de reação que tem acontecido com a inércia estabelecida nos estudos de leitura, literatura e ensino nos meios acadêmicos. A organização da obra já aponta para o diálogo: Victoria Wilson, professora do Curso de Letras; Jaqueline Morais, da área de Educação, apontam para discussões que urgem tomar fôlego nos estudos universitários.

Outro dado bastante interessante se mostra no volume: trata-se do estabelecimento de diálogo necessário entre a escola básica e a universidade, principalmente, quando se leva em conta o público alvo mais provável do volume: professores e alunos do curso de licenciatura na área de Letras, 
Pedagogia e afins. Mas o que se sobreleva nessa conexão não é a presença desse diálogo e sim o protagonismo dos sujeitos e lugares envolvidos nele: são vozes que vêm das escolas e das experiências na biblioteca universitária; são alunos de graduação e professores; legitimando a ideia de que os estudos acadêmicos, muito mais do que falar da escola, devem dar voz a ela na universidade.

E essa boa parceria resulta de processo a priori, a iniciativa de um grupo de pesquisadores investidos da tarefa de revitalizar a biblioteca da universidade. E o desdobramento do trabalho encaminha esse diálogo também, uma vez que, aliados a reflexões teóricas, há encaminhamentos práticos indicados em alguns textos, que servem como ponto de partida para os que desejarem o enveredamento nas searas propostas pelo volume.

Uma coletânea de artigos tem a vantagem sempre de reunir diferentes pesquisas em torno de uma temática maior; entretanto, por vezes o resultado é um painel fragmentado de experiências, que não vincula o leitor na busca de todo a obra necessariamente. Aqui, apesar de textos diferentes e autores diversos, há unidade no volume, conferida por objetivos comuns, especificamente o de refletir sobre as dimensões envolvidas na formação de leitores, pensadas, pelas autoras, como relação de formação de um sujeito implicado da linguagem e seus usos - leitura e escrita, principalmente.

A linguagem em sua dimensão ética, estética e simbólica apresenta-se bem contemplada na obra das autoras, uma vez que os espaços de leitura estudados passam por sala de aula, biblioteca; dão voz a diferentes sujeitos da aprendizagem, da criança em fase inicial de letramento ao aluno da Educação de Jovens e Adultos; percorrem diferentes aspectos, desde a língua e literatura vernáculas até as línguas estrangeiras; e ainda pensa estudos urgentes, mas quase esquecidos nos bancos universitários, como a literatura infantil e juvenil.

Formar leitores é, antes de tudo, reconhecer os sujeitos envolvidos no processo de construção de sentidos, numa perspectiva que coloca o professor como um leitor especializado, sem, entretanto, conferir-lhe status de proprietário das idéias. Dar voz aos leitores, sejam eles alunos ou mesmo professores já em sua atividade profissional, tem sido uma das tarefas mais 
complicadas nesse processo de pensar o leitor. A ideia de levar a experiência aos ambientes de formação parece hoje necessitar de alternância com a de trocar o que se tem com um público que traz consigo uma gama incomensurável de experiências, silenciadas por muitos motivos, dentre os quais o processo de escolarização autoritário que ainda se vive no país é um dos principais motivadores.

Em tempos complexos de produção acadêmica, há de se pensar o lugar do pesquisador e sua responsabilidade junto a sua comunidade, acadêmica ou não, antes de sua relação direta com os resultados que precisa apresentar às agências de fomento. O livro Leitura, escrita e ensino: discutindo a formação de leitores parece responder a essa responsabilidade primeira: com a universidade, com a escola, com a biblioteca, com o município de São Gonçalo. 
Artigo recebido em: 20 de agosto de 2015

Artigo aprovado em: 20 de setembro de 2015

Sobre a autora:

Ana Crélia Penha Dias possui graduação em Letras pela Universidade do Estado do Rio de Janeiro (1994), mestrado em Letras (Letras Vernáculas) pela Universidade Federal do Rio de Janeiro (2003) e doutorado em Letras (Letras Vernáculas) pela Universidade Federal do Rio de Janeiro (2008). Atualmente é professor da Universidade Federal do Rio de Janeiro. 